complexity by adding in only parameters that increase potential valuation.

To be fair, there is at least one realistic drug-development scenario that is more readily captured by real options than by rNPV: A lead compound may fail in a clinical trial for one indication but be reformulated or applied successfully for another indication. One example is sildenafil citrate, which failed to reach its primary endpoint in clinical trials to relieve chest pain, but is now-thanks to a fortuitous side effect-marketed under the trade name Viagra. Having said that, I do not think that valuation simulations would (or should) be taken seriously if billion-dollar windfalls were to be relied on to prop up the value of a marginal project.

As for the need "to claim implausibly high positive project NPVs," risk-adjustment-the " $r$ " in rNPV-relieves this burden and presents a perfectly credible valuation. Indeed, this is the very point of rNPV.

In summary, neither of Harrison and Lerer's reasons for preferring real options to rNPV is particularly compelling. Real options theory seeks to reveal the value of flexibility; in biotechnology, some of these "options" are not "real" at all. Also, both real options and rNPV are equally dependent on accurate market projections. The choice to use rNPV or real options really comes down to the intended audience. If the audience is an investor who is familiar with real options analysis, then by all means use real options. If the audience is unfamiliar with real options, a single price tag-the rNPV—is more likely to convince.

I would also like to take this opportunity to correct an oversight in the rNPV paper ${ }^{2}$. I failed to acknowledge the extremely useful industry parameters periodically published in summary form by Joe DiMasi and colleagues at the Tufts University Center for the Study of Drug Development (http://www.tufts.edu/med/csdd/).

1. Fink, R. CFO Magazine. September, 85-86 (2001).

2. Stewart, J.J. et al. Nat. Biotechnol. 19, 813-817 (2001).

\section{ES cell guidelines in Sweden}

To the editor:

The long-awaited guidelines for stem cell research were issued on December 4 by the board of the Swedish Science Council (http://www.vr.se/press/). During the summer of 2001, the Council had released the proposal to the public to encourage debate about the ethics and acceptability of stem cells research in Sweden.

One reason that these guidelines were approved appears to have been a change in position by Sweden's second-largest party, the Christian Democrats. In late November, the party's leading expertwho was outspoken against any use of embryos in research-was omitted from a working group set up to determine stem cell policy for the party. And on December 2, Christian Democrat leader Alf Svensson wrote an article in a leading Swedish newspaper Dagens Nyheter arguing that “... in a not too-distant future, one could find methods to produce individual specific pluripotent stem cells by inserting a cell nucleus from an individual...into an empty unfertilized egg, which is capable of providing ES cells, but not of totipotency (our translation in italics)". That is, he argued that embryo destruction could be avoided using approaches such as therapeutic cloning or some "as yet unknown method". Most importantly, he concluded that research on ES cells was necessary and should proceed.

The guidelines published by the Swedish Science Council endorse the existing practice of using donated spare embryos from in vitro fertilization (IVF) treatment, call for a legal framework to regulate therapeutic cloning (but find no ethical objections), but at present rule out somatic-cell nuclear transfer using unfertilized eggs. They also state there should be no commerce in embryos; the donors should not gain any financial benefits. However, it remains unclear who controls the use of the ES cell lines. At present, the couple who donates the spare embryo in the IVF clinic used to derive a stem cell line can order destruction of "their" cell line. This has already occurred for one stem cell line, when the donor couple did not consent to continue cultivation beyond the first period granted by the ethics committee. When it is time for international co-operation, the consent of the donor couple must also be obtained for the export of ES cells from Sweden.

Even more troubling, a proposed law on biobanks (PROP 2001/02:44) strengthens the control of ES cell lines by donor couples. The idea seems to be that all research on human tissues, cells, etc. should be treated in the way the Helsinki declaration treats medical research on humans. Even if the Science Council has given green light to human ES cell research, it is imperative these issues be further clarified.

Stellan Welin and Anders Persson, Centre for Research Ethics, Sahlgrenska Academy at Göteborg University, Box 400, 40530 Göteborg, Sweden (swelin@cre.gu.se)

\section{Germany permits import of ES cells}

\section{To the editor:}

On 30 January 2002, the German Parliament voted to permit the importation of embryonic stem (ES) cells for research isolated from so-called surplus in vitro fertilization (IVF) embryos. Although the production of ES cells from human blastocysts is prohibited by the German Embryo Protection Act of 1990, research on existing ES cell lines is not.

There has been intense debate in Germany on the ethical issues surrounding the production and destruction of human embryos for research purposes ever since the first successful isolation of ES cells in 1998. Germans are particularly sensitive about the use of ES cells for research because of the well-known abuses of human rights during the eugenics research of the Nazi era. In May of last year, Germany's main research funding agency, the Deutsche Forschungsgemeinschaft (DFG), issued guidelines to permit import of, and research on, ES cells. This was encouraging for Otmar Wiestler and Oliver Brüstle of the University of Bonn, two neuropathologists who had previously submitted a proposal around one year before the guidelines were issued. Public criticism was such, however, that the Research Ministry and National Ethics Council-a committee recently established by Chancellor Gerhard Schröder-were moved to ask the DFG to delay funding for Wiestler and Brüstle with the aim of allowing more time for discussion.

Three legislative proposals were discussed by the German Bundestag: Proposal 1, which prohibited the importation of ES cells and called for a complete ban on ES cell research; Proposal 2, which permitted ES cell research under very strict limits and regulations, but only on cell lines imported from elsewhere and legally isolated solely from surplus IVF embryos; and Proposal 3, which permitted both the import and the generation in Germany of ES cells without special restrictions from surplus IVF embryos.

In a final ballot, which differed fundamentally from conventional procedures because the parliamentarians were exempted from voting along party lines, Proposal 2 passed with a majority of 75 . One day after Parliament's decision, the DFG approved the only application for ES cell research, submitted by Wiestler and Brüstle 18 months before.

Fuat S. Oduncu,
Medical Faculty of the University of Munich
Munich, Germany
(Fuat.Oduncu@lrz.uni-muenchen.de)

